\title{
Combined fertilizers versus dolomitic limestone: A comparative study from a forest habitat with Norway spruce
}

\author{
Aleš Kučera ${ }^{1 *}$, Jana Rosíková ${ }^{1}$, Jan Pecháček ${ }^{3}$, Peter Dundek ${ }^{1}$, Dušan Vavříček ${ }^{2}$ \\ ${ }^{1}$ Mendel University in Brno, Department of Geology and Pedology, Zemědělská 3, CZ - 61300 Brno, Czech Republic \\ ${ }^{2}$ Mendel University in Brno, Department of Forest Botany, Dendrology and Geobiocenology, Zemědělská 3, \\ CZ-613 00 Brno, Czech Republic \\ ${ }^{3}$ Forest Management Institute, Brandýs nad Labem, Vrázova 1, CZ - 61600 Brno - Žabovřesky, Czech Republic
}

\begin{abstract}
The research paper with character of case study deals with the influence of amelioration on soil as well as the Norway spruce nutrition and growth, with the focus on dolomitic limestone and combined fertilizer applications. The study was performed in the 7-year-old forest stand (Nízký Jeseník Mountains, Czech Republic, 100\% Norway spruce, podzol, mor humus form, slightly undulated slope, $770 \mathrm{~m}$ a.s.l.). The soil properties (soil reaction, nutrient status, $\mathrm{C} / \mathrm{N}$ ratio and cation exchange capacity), the plant nutrition, the plant biomass production and the health status were measured. Neither the expected significant increase in $\mathrm{pH}$ due to liming in the root zone nor the increase in calcium and magnesium in the soil was confirmed. In the dolomitic limestone treatment, the highest hydrolytic acidity reaching $260 \mathrm{mmol}_{+} / \mathrm{kg}$, the worst development of assimilatory organs, the growth and health status of individuals were ascertained one year after the usage. The application of combined fertilizers resulted in the highest response in the needle biomass production $(0.35 \mathrm{~g} / 100$ needles compared to less than $0.30 \mathrm{~g} / 100$ needles in the dolomitic limestone treatment), in the potassium and phosphorus nutrition status (suboptimal $4-4.5 \%$ of potassium in dolomitic limestone and the control treatment compared to optimal 5.5-7.5\% in the combined fertilizers treatments) and simultaneously to the optimization of the health status. Specifically, in forest stands, the effect of dolomitic limestone is rather overestimated and furthermore, chemical amelioration requires the detailed knowledge of the forest site.
\end{abstract}

Key words: forest soil; acidification; reclamation practice; plant nutrition; nutrient antagonism

Editor: Erika Gömöryová

\section{Introduction}

Soil acidification, defined as the decrease in the neutralization capacity (Merry 2009), is the process by which the base cation content is reduced and the acidic cation content is increased (Singh \& Agrawal 2008). The alteration in soil chemistry originates from the contradictory effect of acidifying or alkalizing factors and the soil buffering capacity (Huang et al. 2014). In humid climate, in particular, soil acidification occurs through various natural mechanisms (Hruška \& Ciencala 2005; Merry 2009). Numerous authors have attached minimal importance to natural acidification mechanisms in comparison with anthropogenic acidification (Ingerslev 1999; Ingerslev \& Hallbäcken 1999), associated with the forest dieback linked to the acid deposition of atmospheric pollutants (Bäck et al. 1995) and inappropriate woody species compositions (Augusto et al. 2002).
Over the past several decades, the elimination of anthropogenic acidification in the Czech Republic has been predominantly based on aerial liming of forest stands (Klimo and Vavříček 1991; Kuneš 2003; Vavř́iček et al. 2005; Novotný et al. 2008; Kulhavý et al. 2009; Baláš et al. 2010; Srámek et al. 2012).

However, the outcomes of the liming measures have frequently been inconsistent due to the specificities of forest habitats and forest soils in general (Kreutzer 1995; reviewed for Central-European conditions by Hruška \& Ciencala 2005) and many authors have been concerned with the use of combined fertilizers rather than largescale aerial liming (Lomský et al. 2006; Vacek et al. 2006) for the soil environment and mainly forest stand health and nutrition status improvement. Some of the studies mention a risk joined with forest soil amelioration and only short-term effectiveness in regards to forest production and health status, especially in large scale area applications. 
The application of combined slow-release mineral fertilizers on an individual basis to each transplant has been implemented by several authors (Kuneš et al. 2013; Pecháček et al. 2017). These fertilizers have demonstrated the impact on the optimization of the nutrient and health status of plants and the soil environment. The effect of fertilizers can be accentuated by using growth regulators (Simpson 1986; Seaby \& Selby 1990), such as NAA Na${ }^{+}, \mathrm{SNP} \mathrm{Na}{ }^{+}$and IBA K ${ }^{+}$.

The scientific treatise reflects on the effect of forest soil amelioration on the soil and the forest stands at the juvenile stage of planted Norway spruce (Picea abies [L.] H. Karst), focusing on a comparison of different ameliorative materials including combined fertilizers and dolomitic limestone. The hypothesis was based on the mentioned presumptions that dolomitic limestone is the less effective ameliorative material for soil amelioration, the plant growth as well as the health and nutrition status optimization compared to combined fertilizers. We presumed weak amelioration effect of the dolomitic limestone in contrast to combined fertilizers in the Norway spruce conditions with regards to $\mathrm{pH}$ and base saturation improvement nor nutrient status optimization.

\section{Materials and methods}

The case study study was performed in the 7-year-old forest stand (100\% Norway spruce; Nízký Jeseník Mountains, Solná hora Mountain, Czech Republic; GPS coordinates $50.2095833 \mathrm{~N}, 17.4506389 \mathrm{E})$. The effects were tested for the presence of compound fertilizers with a specific composition of macronutrients (Table 1) and growth regulators and dolomitic limestone, compared to the control treatment.
Site Description (Table 2): The soil was covered by $100 \%$ with dominance of Calamagrostis epigejos (80\%), Avenellaflexuosa (30\%), Senecio Fuchsii (10\%) and bryophytes. The soil taxonomical unit was Entic Skeletic Podzols (Loamic) (IUSS Working Group WRB 2014) with the mor humus form of 6-8 cm thickness; $770 \mathrm{~m}$ a.s.l.; slightly undulated slope; $\mathrm{N}-\mathrm{W}$ exposition (azimuth $285^{\circ}$ ); slope inclination $21 \%$; annual mean precipitation $800 \mathrm{~mm}$; mean air temperature $6.8^{\circ} \mathrm{C}$; annual mean soil moisture at 8 and $20 \mathrm{~cm}$ depth $27.8 \%$ vol. and $27.4 \%$ vol., respectively; annual mean soil temperature at 8 and $20 \mathrm{~cm}$ depth $6.7^{\circ} \mathrm{C}$ and $6.8^{\circ} \mathrm{C}$, respectively.

The soil is characteristic of the dominant podzolization soil-forming process on the shallow soil forming substrate of carboniferous graywacke mixed with clay shale partially metamorphosed to argillaceous schist inclined in angle of $60-75^{\circ}$ to the soil surface with stoniness of $80-90 \%$ in the soil forming substrate, $50-70 \%$ in subsoil and $30-50 \%$ near the soil surface, which is very substantial for water regime and water drainage of the habitat in relation to water, as well as nutrient availability.

The rectangular research plot $(120 \times 150 \mathrm{~m})$ was parcelled out to obtain six identical zones with the dimensions of $20 \times 150 \mathrm{~m}$ containing 180 to 200 regularly distributed individuals per treatment. The treatment distribution on the plot was performed randomly. $160 \mathrm{~g}$ of the ameliorative material was applied individually to the soil surface within the crown projection on the individual basis (cca $80-120 \mathrm{~cm}$ in diameter which is cca 0.50 $-1.13 \mathrm{~m}^{2}$ which would correspond to doses of 1.4-3.2t of the ameliorant per ha) of each treated spruce in April 2014 and 2015.

The data collection was conducted in October 2015 via (1) mixed soil samples: 5 replicates per treatment (from the root zone under organic horizons; sampling

Table 1. Overview of the treatments and the composition of the tested ameliorative materials.

\begin{tabular}{|c|c|c|c|c|c|c|c|c|}
\hline \multirow[t]{2}{*}{ Treatment symbol } & \multirow[t]{2}{*}{ Trade mark / form ${ }^{1}$} & \multicolumn{6}{|c|}{$\begin{array}{c}\text { Nutrient concentration } \\
{[\%]}\end{array}$} & \multirow{2}{*}{$\begin{array}{c}\text { Plant growth } \\
\text { regulators } \\
{[\%]}\end{array}$} \\
\hline & & $\mathrm{N}$ & $\mathrm{P}$ & $\mathrm{K}$ & $\mathrm{Mg}$ & $\mathrm{Ca}$ & $\mathrm{S}$ & \\
\hline $\bar{C}$ & (Control) & - & - & - & - & - & - & - \\
\hline SR50_s2 & Silvamix ${ }^{\circledR} \mathrm{R} 50+\mathrm{s} 2$ & $14.5^{1}$ & 3.08 & 14.94 & 3.0 & - & 1.3 & 0.17 \\
\hline SR_S & Silvamix ${ }^{\circledR} \mathrm{R} 30+\mathrm{s}$ & $10.0^{2}$ & 3.08 & 14.94 & 4.5 & - & 4.3 & 0.35 \\
\hline SR & Silvamix ${ }^{\circledR} \mathrm{R} 30$ & $10.0^{2}$ & 3.08 & 14.94 & 4.5 & - & 4.3 & - \\
\hline SA_s2 & AGLUFORM $^{\circledR 90+s 2}$ & $19.0^{2}$ & 3.08 & 9.13 & 2.88 & - & 4.0 & 0.17 \\
\hline DolLim & Dolomitic limestone & - & - & - & 11.22 & 22.9 & - & - \\
\hline
\end{tabular}

${ }^{1} 55 \%$ of $\mathrm{N}$ as urea-formaldehyde;

${ }^{2} 34 \%$ of $\mathrm{N}$ as urea-formaldehyde;

${ }^{3}$ when $0.17 \%$ : NAA Na+ $0.025 \%$; DA- $60.07 \%$; SNP Na+ $0.05 \%$; IBA K + 0.025\%;

when $0.35 \%$ : NAA Na+ 0.15\%; DA-6 0.10\%; SNP Na+ 0.075\%; IBAK + 0.025\%.

Table 2. Properties of the soil profile in FS Solná hora Mountain within the different soil layers.

\begin{tabular}{|c|c|c|c|c|c|c|c|c|c|c|c|c|}
\hline \multirow{3}{*}{ Soil layer characteristics } & \multirow{3}{*}{$\begin{array}{l}\text { Sampling depth } \\
{[\mathrm{cm}]}\end{array}$} & \multicolumn{9}{|c|}{ Nutrient Content } & \multirow{3}{*}{$\begin{array}{c}\mathrm{CEC} \\
{\left[\mathrm{mmol}_{+} / \mathrm{kg}\right]}\end{array}$} & \multirow{3}{*}{$\begin{array}{l}\text { BS } \\
{[\%]}\end{array}$} \\
\hline & & \multicolumn{2}{|c|}{$\mathrm{pH}$} & Corg & $\mathrm{Nt}$ & $\mathrm{C} / \mathrm{N}$ & $\mathrm{P}$ & $\mathrm{Mg}$ & $\mathrm{Ca}$ & $\mathrm{K}$ & & \\
\hline & & $\mathrm{H}_{2} \mathrm{O}$ & $\mathrm{KCl}$ & \multicolumn{2}{|c|}{ [\%] } & & \multicolumn{4}{|c|}{$[\mathrm{mg} / \mathrm{kg}]$} & & \\
\hline Organomineral & $12-17$ & 3.93 & 2.94 & 8.17 & 0.40 & 20 & 29 & 306 & 864 & 31 & 379.3 & 18.2 \\
\hline Eluvial & $19-25$ & 4.01 & 3.21 & 5.41 & 0.28 & 19 & 30 & 162 & 384 & 25 & 312.9 & 10.6 \\
\hline Spodic & $34-44$ & 4.21 & 3.72 & 5.16 & 0.27 & 19 & 73 & 75 & 216 & 20 & 271.5 & 6.4 \\
\hline \multirow[t]{2}{*}{ Soil forming substrate } & $60-80$ & 4.37 & 4.10 & 2.35 & 0.14 & 17 & 71 & 41 & 182 & 9 & 154.3 & 8.2 \\
\hline & & & & & & & $2390 *$ & $21819^{*}$ & $46862 *$ & $19540^{*}$ & & \\
\hline
\end{tabular}

Corg - organic carbon; Nt - total nitrogen; CEC - cation exchange capacity; BS - base saturation; *total element content in substrate horizon using hydrofluoric acid. 
depth 8-12 cm; below the crown projection); each replicate was composed of 3 individual samples; (2) mixed samples of needles: 3 replicates per treatment (from the upper third of the crown; from last two shoot year-classes separately as one-year-old and two-year-old needles); each sample was comprised of needles from 10 to 15 individuals; and (3) biometric data: 50 individuals per treatment.

The soil was analysed to assess the soil reaction $(\mathrm{pH} /$ $\mathrm{H}_{2} \mathrm{O}$ and $\mathrm{pH} / \mathrm{KCl}$ ) in the soil: the eluent ratio of 1:2.5 (w:v); $\mathrm{H}^{+}$concentration [ $\left.\mathrm{mmol}_{+} / \mathrm{kg}\right]$ using dual $\mathrm{pH}$ measurement (Adams \& Evans 1990); available mineral nutrients $(\mathrm{Ca}, \mathrm{Mg}, \mathrm{K})[\mathrm{mg} / \mathrm{kg}]$ from Mehlich II leachate (Mehlich 1978); P content [mg/kg] using spectrophotometry in a solution of ascorbic acid, $\mathrm{H}_{2} \mathrm{SO}_{4}$ and $\mathrm{Sb}^{3+}$; organic carbon $\left(\mathrm{C}_{\text {org }}\right)$ [\%] content spectrophotometrically in a chromosulphuric acid; total nitrogen $\left(\mathrm{N}_{\mathrm{t}}\right)$ [\%] content using the Kjeldahl method in \% (Kirket al. 1950); sulphur content [g/kg] using Regulation (EC) 2003/2003; mobile $\mathrm{Al}^{3+}$ content $\left[\mathrm{mmol}_{+} / \mathrm{kg}\right]$ (Sokolov 1939); cation exchange capacity (CEC) $\left[\mathrm{mmol}_{+} / \mathrm{kg}\right]$ using a summation method; base saturation (BS) [\%] using the equation $\mathrm{BS}=\left(\mathrm{Ca}^{2+}\right.$ $+\mathrm{Mg}^{2+}+\mathrm{K}^{+}$) / CEC; the particular cation content using the equation $\mathrm{Cmmol}=\mathrm{Cmg} /(\mathrm{M} / \mathrm{Oxn})$, where $\mathrm{Cmmol}$ is the nutrient concentration in $\mathrm{mmol}_{+} / \mathrm{kg}$; $\mathrm{Cmg}$ is the nutrient concentration in $\mathrm{mg} / \mathrm{kg}$; $\mathrm{M}$ is the element molar mass, and Oxn is the nutrient oxidation number; the total element content in the soil substrate using mineralization in hydrofluoric acid. The total nutrient amount in the soil sample was reduced when $\mathrm{C}_{\text {org }}$ content exceeded $7.25 \%$ (12.5\% of humus) using the equation $\mathrm{Sn}=\mathrm{S}_{\mathrm{N} \text {-anal }} /\{1 /$ $\left.\left[\left(100-\mathrm{H}_{\mathrm{ox}}\right) / \mathrm{H}_{\mathrm{ox}}\right] \cdot 7\right\}$, where $\mathrm{S}_{\mathrm{N}-\text { anal }}$ is the nutrient content in $\mathrm{mg} / \mathrm{kg} ; \mathrm{H}_{\mathrm{ox}}$ is the humus content $\left(\mathrm{C}_{\mathrm{org}} \cdot 1.724\right)$ and 7 is the empirical value (Vavř́ček \& Kučera 2017). The cation ratio in molar mass was used to obtain the $\mathrm{Ca} / \mathrm{Al}$ and $\mathrm{Bc} /$ $\mathrm{Al}$ ratios where the $\mathrm{Bc}$ is the sum of base cations.

Biomass was analysed to assess the contents of macrobioelements [ $\mathrm{N}$ in \%; $\mathrm{P}, \mathrm{K}, \mathrm{Ca}, \mathrm{Mg}, \mathrm{S}$ in $\mathrm{g} / \mathrm{kg}$ ] (Strížová 2014). The nutrient ratio was used in oneyear-old and two-year-old needles separately to obtain the $\mathrm{Ca} / \mathrm{Mg}, \mathrm{K} / \mathrm{Mg}, \mathrm{Ca} / \mathrm{N}$ and $\mathrm{Mg} / \mathrm{N}$ ratios. Biometry was assessed for annual height increment [cm], weight of 100 needles dried at $105^{\circ} \mathrm{C}[\mathrm{g}]$ and health status $(1-$ the best to 5 - the worst).

Data processing was performed with R software, version 3.6.2 (2019-12-12) and RStudio, version 1.2.5033. As graphical tools, we used the boxplot graphs (the boxes show medians and quantiles 0.25 and 0.75 ) and plotting with $95 \%$ confidence intervals in case of parametric multiple comparison, using 'plotmeans' function from package 'gplots' version 3.0.1.2. We applied the parametric and nonparametric analyses of variance (ANOVA, Kruskal-Wallis test, respectively), the parametric and nonparametric post-hoc analyses (Tukey HSD and nonparametric multiple comparison - nonparametric relative contrast effect with "Tukey" type of contrast, respectively). The normality was tested using Shapiro-Wilk test with $\alpha=0.05$. The Principal component analysis (PCA) was performed with the 'vegan' package version 2.4-3 after data standardization.

The abbreviations used in the graphical figures are as follows: Soil_C_N - C/N ratio; Soil_pH_H $\mathrm{H}_{2} \mathrm{O}$ and Soil_pH_KCl - active and exchangeable soil reaction, respectively; Soil_Ca, Mg, K, P, S, Nt, H - element content in soil; Soil_BS - base saturation; Soil_CEC - cation exchange capacity; Nutr_P, Mg, Ca, K, N, S, CaMg, $\mathrm{KMg}$ - nutrient content in needles and the nutrient ratio; HundrNeedl - weight of 100 needles; GrowAnn - annual height increment; Health - health status. The individual treatment variants in the experiment are labelled according to Table 1.

\section{Results}

The high variability of the soil properties resulted in the use of the nonparametric tests, which revealed the differences among all the parameters.

The soil reaction was strongly acidic for all the treatments, with the lowest acidity observed in C (Fig. 1; see also Table 3). The soil exchangeable reaction was the lowest for the DolLim, which also had the most variable values.

Based on Table 3, merely the control treatment (C) was typical of the statistically different (higher) values of
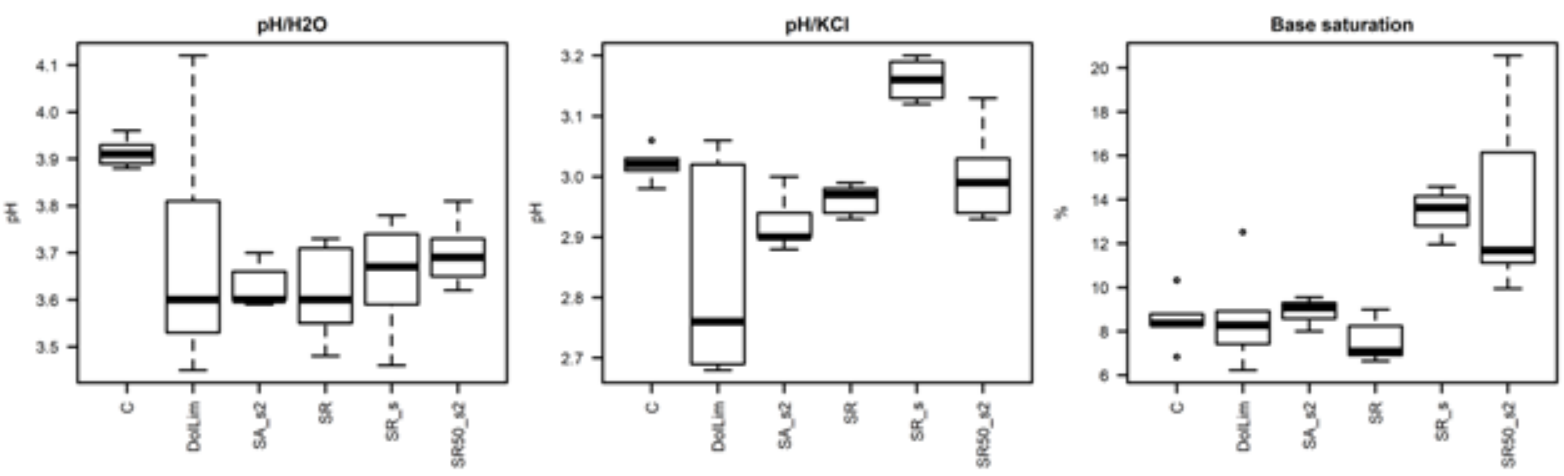

Fig. 1. Physical-chemical soil parameters in the individual treatments in the organo-mineral soil horizon (for the abbreviations, explanations see Materials and Methods Section and Table 1). 
the active soil reaction while the exchangeable reaction was more diverse (the lowest in DolLim and the highest in SR_s). However, the values of $\mathrm{pH} / \mathrm{H}_{2} \mathrm{O}$ in the control treatment correspond with the natural situation in the soil (cf. with Table 2) while in other treatments the soil reaction was lower and close to the natural situation in the treatments SA_s2 and SR in case of $\mathrm{pH} / \mathrm{KCl}$.

Base saturation was the lowest in SR but statistically equal with C, DolLim and SA_s2 while the BS of the treatments SR_s and SR50_s2 was even above $10 \%$. In all the treatments the BS was markedly lower than in the natural soil.

Using fertilizers, the nutrient content in the soil (Fig. 2, Table 4) was optimized or even supraoptimized in case of $\mathrm{K}$ and partially also for $\mathrm{P}$ while the $\mathrm{Mg}$ and Ca contents were suboptimal neither in the natural soil, typical of medium or high values nor in mineral (eluvial) horizon. The nitrogen content was the highest in DolLim (not significantly) and the lowest in SR - in all the treatments in high levels, which can be related to the elevated organic carbon content in the whole soil profile (Table 2), bonding nitrogen, as well as other nutrients via cation exchange. The $\mathrm{C} / \mathrm{N}$ ratio was in the optimal values which could even seem to be untypical of the forest soil with Norway spruce. ANOVA revealed significantly higher $\mathrm{C} / \mathrm{N}$ ratio in the treatments with DolLim and SR50_s2 which are still in the optimal values. Such high nitrogen content is probably due to high stoniness and organic matter infiltration to the depth, being characteristic of leptic soils. Acid cations, both $\mathrm{H}^{+}$as well as $\mathrm{Al}^{3+}$, are highly concentrated with the significant differences in all the treatments with the highest values surprisingly in Dol-
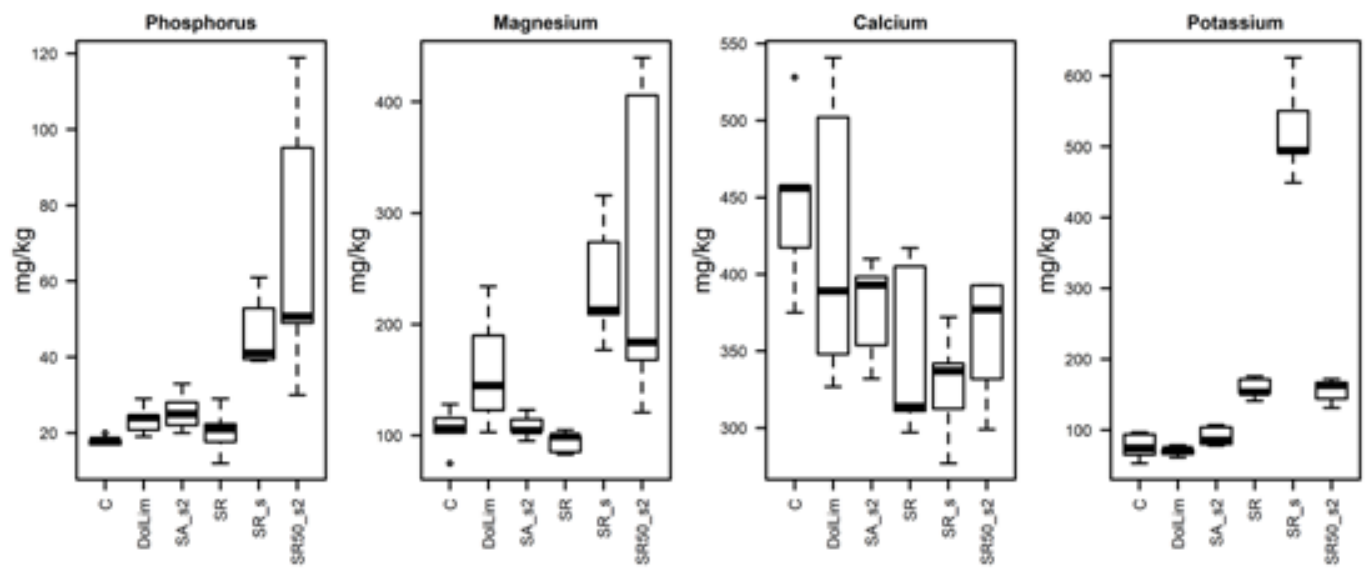

Fig. 2. Exchangeable nutrients content (Mehlich II) in the soil in the individual treatments in the organo-mineral soil horizon (for the abbreviations, explanations see Materials and Methods Section and Table 1).

Table 3. Mean values and results of statistical testing of the physical-chemical soil parameters in the individual treatments in the organo-mineral soil horizon.

\begin{tabular}{|c|c|c|c|c|c|c|c|c|c|}
\hline Parameter & Units & $\mathrm{C}$ & DolLim & SA_s2 & SR & SR_S & SR50_s2 & Test Type & p-value \\
\hline $\mathrm{pH} / \mathrm{H}_{2} \mathrm{O}$ & - & $3.91^{\mathrm{a}}$ & $3.70^{b}$ & $3.63^{b}$ & $3.61^{\mathrm{b}}$ & $3.65^{\mathrm{b}}$ & $3.70^{b}$ & aov & * \\
\hline $\mathrm{pH} / \mathrm{KCl}$ & - & $3.02^{\mathrm{ab}}$ & $2.84^{\mathrm{b}}$ & $2.92^{\mathrm{ab}}$ & $2.96^{\mathrm{ab}}$ & $3.16^{\mathrm{a}}$ & $3.00^{\mathrm{ab}}$ & aov & $* * *$ \\
\hline CEC & $\mathrm{mmol}_{+} / \mathrm{kg}$ & $387.2^{\mathrm{a}}$ & $417.1^{\mathrm{a}}$ & $337.9^{\mathrm{b}}$ & $386.2^{\mathrm{a}}$ & $366.8^{\mathrm{b}}$ & $314.7^{b}$ & aov & $* * *$ \\
\hline $\mathrm{Bc}$ & $\mathrm{mmol}_{+}^{+} / \mathrm{kg}$ & $33.0^{\mathrm{b}}$ & $36.0^{\mathrm{b}}$ & $30.0^{\mathrm{b}}$ & $29.4^{b}$ & $49.4^{\mathrm{a}}$ & $43.4^{b}$ & K-W & * \\
\hline BS & $\%$ & $8.5^{\mathrm{b}}$ & $8.7^{\mathrm{b}}$ & $8.9^{\mathrm{b}}$ & $7.6^{\mathrm{b}}$ & $13.4^{\mathrm{a}}$ & $13.9^{\mathrm{a}}$ & $\mathrm{K}-\mathrm{W}$ & $* *$ \\
\hline
\end{tabular}

Superscripts following the mean values denote mutual statistical differences at $\alpha=0.05$ on the basis of the post-hoc multiple comparison (test type: "aov" - parametrical ANOVA; "K-W" - KruskalWallis test; p-values: “***” $<0.001 ;$ “** ” 0.001-0.01; “* ” 0.01-0.05; “.” 0.05-0.1). For the abbreviations, explanations see Materials and Methods Section and Table 1.

Table 4. Mean values and results of statistical testing of the nutrient content, the $\mathrm{C} / \mathrm{N}$ ratio, the acid cations content and the $\mathrm{Ca} / \mathrm{Al}$ and $\mathrm{Bc} / \mathrm{Al}$ ratios in the individual treatments in the organo-mineral soil horizon.

\begin{tabular}{|c|c|c|c|c|c|c|c|c|c|}
\hline Parameter & Units & $\mathrm{C}$ & DolLim & SA_s2 & SR & SR_S & SR50_s2 & Test Type & $\mathrm{p}$-value \\
\hline$\overline{\mathrm{P}}$ & & $18.0^{\mathrm{b}}$ & $23.5^{\mathrm{b}}$ & $25.6^{\mathrm{b}}$ & $20.4^{b}$ & $46.7^{\mathrm{a}}$ & $68.8^{a}$ & $\mathrm{~K}-\mathrm{W}$ & $* * *$ \\
\hline $\mathrm{Mg}$ & & $105.5^{\mathrm{b}}$ & $158.9^{\mathrm{a}}$ & $108.2^{\mathrm{b}}$ & $94.3^{\mathrm{b}}$ & $237.7^{\mathrm{a}}$ & $263.7^{\mathrm{a}}$ & $\mathrm{K}-\mathrm{W}$ & $* *$ \\
\hline $\mathrm{Ca}$ & $\mathrm{mg} / \mathrm{kg}$ & $446.7^{\mathrm{a}}$ & $421.4^{b}$ & $377.4^{\mathrm{b}}$ & $348.8^{b}$ & $328.1^{\mathrm{b}}$ & $358.7^{\mathrm{b}}$ & aov & * \\
\hline K & & $76.6^{\mathrm{b}}$ & $70.0^{\mathrm{b}}$ & $90.8^{b}$ & $158.8^{\mathrm{ab}}$ & $522.2^{\mathrm{a}}$ & $155.5^{\mathrm{ab}}$ & $\mathrm{K}-\mathrm{W}$ & $* * *$ \\
\hline $\mathrm{N}$ & $\%$ & $0.34^{\mathrm{a}}$ & $0.41^{\mathrm{a}}$ & $0.31^{\mathrm{a}}$ & $0.27^{\mathrm{b}}$ & $0.34^{\mathrm{a}}$ & $0.32^{\mathrm{a}}$ & $\mathrm{K}-\mathrm{W}$ & \\
\hline $\mathrm{C} / \mathrm{N}$ & - & $18.7^{\mathrm{b}}$ & $23.1^{\mathrm{a}}$ & $20.3^{\mathrm{b}}$ & $20.2^{\mathrm{b}}$ & $15.3^{\mathrm{b}}$ & $23.3^{\mathrm{a}}$ & aov & $* * *$ \\
\hline $\mathrm{H}^{+}$ & & $199.0^{\mathrm{ab}}$ & $226.9^{\mathrm{a}}$ & $206.8^{\mathrm{a}}$ & $187.5^{\mathrm{b}}$ & $189.2^{\mathrm{b}}$ & $184.5^{b}$ & $\mathrm{~K}-\mathrm{W}$ & * \\
\hline $\mathrm{Al}^{3+}$ & $\mathrm{mmol}_{+} / \mathrm{kg}$ & $155.2^{\mathrm{a}}$ & $154.4^{\mathrm{a}}$ & $101.0^{\mathrm{b}}$ & $169.5^{\mathrm{a}}$ & $128.2^{\mathrm{ab}}$ & $86.6^{\mathrm{b}}$ & $\mathrm{K}-\mathrm{W}$ & $* * *$ \\
\hline $\mathrm{Ca} / \mathrm{Al}$ & - & $0.14^{b}$ & $0.14^{\mathrm{b}}$ & $0.19^{\mathrm{a}}$ & $0.10^{\mathrm{b}}$ & $0.13^{\mathrm{b}}$ & $0.21^{\mathrm{a}}$ & aov & $* * *$ \\
\hline $\mathrm{Bc} / \mathrm{Al}$ & - & $0.21^{\mathrm{b}}$ & $0.23^{\mathrm{b}}$ & $0.30^{\mathrm{a}}$ & $0.17^{\mathrm{b}}$ & $0.39^{\mathrm{a}}$ & $0.52^{\mathrm{a}}$ & $\mathrm{K}-\mathrm{W}$ & $* * *$ \\
\hline
\end{tabular}

Superscripts following mean values denote mutual statistical differences at $\alpha=0.05$ on the basis of post-hoc multiple comparison (test type: "aov" - parametrical ANOVA; "K-W" - Kruskal-Wallis test; p-values: “*** " $<0.001 ; “ * *$ " $0.001-0.01 ; “ *$ " $0.01-0.05 ;$ “.” 0.05-0.1). For the abbreviations, explanations see Materials and Methods Section and Table 1. 
Lim, and rather equal in all the variants with the lowest in SR50_s2, respectively.

The response of the trees within the treatments was marked more in the plant nutrition than in biometrics. The annual growth was evaluated as almost being equal (Table 5), nevertheless, the highest in SR_s and SR50_ $\mathrm{s} 2$ treatments and the lowest in DolLim followed by the control. Needle biomass was diversified in one-year-old needles with the most massive biomass in SR_s and the least massive in DolLim. The DolLim treatment was also distinctive to the worst health status (decolouration, multicoloured needles, etc.).

Compared to the soil nutrient content, the plant nutrition was specific for rather normal data distribution (Table 6) and the significant differences among the treatments. In two-year-old needles the lowest and the highest content of P was in DolLim and SR50_s2, respectively.

Among the macrobioelements which were mostly contained in the optimal concentrations (mainly $\mathrm{Mg}, \mathrm{Ca}$ ), $\mathrm{S}$ and $\mathrm{K}$ occurred in the low limit values. The sulphur content was markedly lower (on the lower optimum limit) in one-year-old needles in C and DolLim treatments while potassium was deeply below the optimal values in both needle years in the treatments. The nitrogen content was the lowest in $\mathrm{C}$ and DolLim in both years of needles - in two-year-needles even below the optimum limit in DolLim. The nutrient ratio is rather in the optimal values except for DolLim in $\mathrm{Ca} / \mathrm{Mg}$ due to the extremely low Ca content and except for $\mathrm{C}$ and DolLim in $\mathrm{K} / \mathrm{Mg}$ due to the extremely low $\mathrm{K}$ content. The proportions of $\mathrm{Ca} / \mathrm{N}$ and $\mathrm{Mg} / \mathrm{N}$ were found as optimal, however significantly differentiated according to the treatment.

\section{Discussion}

Chemical amelioration, namely liming, substantially affects organic horizons especially on humus-rich sites (Nilsson et al. 2001; Hruška \& Ciencala 2005). The alterations are performed mainly in soil organic layers in the sense of intensive mineralization and related bio- logical/biochemical processes. In our study, we reached the lower $\mathrm{pH}$ values in all the treatments compared to the control one. The phenomenon of the distinct soil chemistry is not necessarily grounded in the treatments. However, we applied either alkaline or physiologically acidic ameliorative materials which can lead to the decrease of $\mathrm{pH}$ below surface organic layers for different reasons (Huettl \& Zoettl 1993). As we sampled the soil in the rooting zone typical of the wide range of natural reasons for soil acidification, such as root exudates and nutrient uptake or also stimulation of plant metabolism using phytostimulants, which lead to lower $\mathrm{pH} / \mathrm{H}_{2} \mathrm{O}$ values.

The mean values of the soil exchange reaction properties showed the least favourable state in the DolLim, even with the respect to base saturation which was the highest in SR_s and SR50_s2 treatments. The nutrient contents in the soil (Fig. 2 and Table 4), as well as in needles (Fig. 3 ) indicated the antagonism of bivalent cations with potassium, which was significantly suppressed. Despite the assumptions stated in the literature (Formánek \& Vránová 2003), the concentration of acidic protons and, notably, aluminium $\left(\mathrm{Al}^{3+}\right)$ was not reduced; this finding was accompanied by very strong hydrolytic acidity.

Our results demonstrated that there was an increased concentration of protons bound to the soil sorption complex (see also Fig. 1 and Table 4), which occupied over 90\% CEC. After displacement from the soil sorption complex, these protons moved downwards into the root zone of the soil profile, increasing the risk of elevated aluminium mobility (see also Matzner 1992).

With regard to excessive soil chemistry alterations caused by chemical amelioration, the issues related to potassium are fundamental, yet little is known about them (Sardans \& Peñuelas 2015). The presence of potassium in the soil can particularly be ensured by a targeted supply of fertilizers (cf. Fig. 2), and, in contrast, a high susceptibility to leaching by antagonistic bases can cause an imbalance in the soil trophic state in the root zone. This finding was also confirmed in the DolLim treatment, which had a significant excess of $\mathrm{Ca}^{2+}$ and $\mathrm{Mg}^{2+}$ and in SA_s2 due to the excessive dosage of a monova-

Table 5. Mean values and results of statistical testing of shoot biomass and the health status of the individuals in the individual treatments.

\begin{tabular}{|c|c|c|c|c|c|c|c|c|c|}
\hline Parameter & Units & $\mathrm{C}$ & DolLim & SA_s2 & $\begin{array}{ll}\text { mean } & \text { SR } \\
\end{array}$ & SR_S & SR50_s2 & Test Type & $\mathrm{p}$-value \\
\hline Annual growth & $\mathrm{cm}$ & 54.3 & 48.0 & 57.9 & 55.9 & 62.2 & 62.1 & $\mathrm{~K}-\mathrm{W}$ & \\
\hline Health & - & $2.0^{\mathrm{a}}$ & $2.7^{\mathrm{b}}$ & $1.9^{\mathrm{a}}$ & $1.6^{\mathrm{a}}$ & $1.8^{\mathrm{a}}$ & $1.7^{\mathrm{a}}$ & $\mathrm{K}-\mathrm{W}$ & *** \\
\hline 100 needles (1st yr) & $\mathrm{g}$ & $0.30^{\mathrm{b}}$ & $0.28^{\mathrm{b}}$ & $0.32^{\mathrm{b}}$ & $0.31^{\mathrm{b}}$ & $0.36^{\mathrm{a}}$ & $0.31^{\mathrm{b}}$ & aov & ** \\
\hline 100 needles ( 2 nd yr) & $\mathrm{g}$ & 0.39 & 0.41 & 0.38 & 0.38 & 0.42 & 0.37 & aov & $>0.1$ \\
\hline
\end{tabular}

Table 6. Results of the variance analysis of the nutrient content and the ratio in assimilatory organs separately for one-year-old and two-year-old needles of the individuals in the individual treatments at $\alpha=0.05$.

\begin{tabular}{|c|c|c|c|c|c|c|c|c|c|c|c|}
\hline Needle Age & Parameter & $\mathrm{P}$ & $\mathrm{Mg}$ & $\mathrm{Ca}$ & K & $\mathrm{N}$ & S & $\mathrm{Ca} / \mathrm{Mg}$ & $\mathrm{K} / \mathrm{Mg}$ & $\mathrm{Ca} / \mathrm{N}$ & $\mathrm{Mg} / \mathrm{N}$ \\
\hline \multirow{2}{*}{ 1st yr } & Test Type & aov & aov & aov & K-W & aov & aov & $\mathrm{aov}$ & $\mathrm{K}-\mathrm{W}$ & aov & aov \\
\hline & $\mathrm{p}$-value & $* * *$ & $* * *$ & $* * *$ & $* * *$ & $* * *$ & $* * *$ & $* * *$ & $* * *$ & *** & $* * *$ \\
\hline \multirow{2}{*}{ 2nd yr } & Test Type & aov & aov & aov & aov & aov & aov & aov & $\mathrm{K}-\mathrm{W}$ & aov & aov \\
\hline & $p$-value & $* * *$ & $* * *$ & * & $* * *$ & $* *$ & * & $* * *$ & $* * *$ & $* *$ & $* * *$ \\
\hline
\end{tabular}



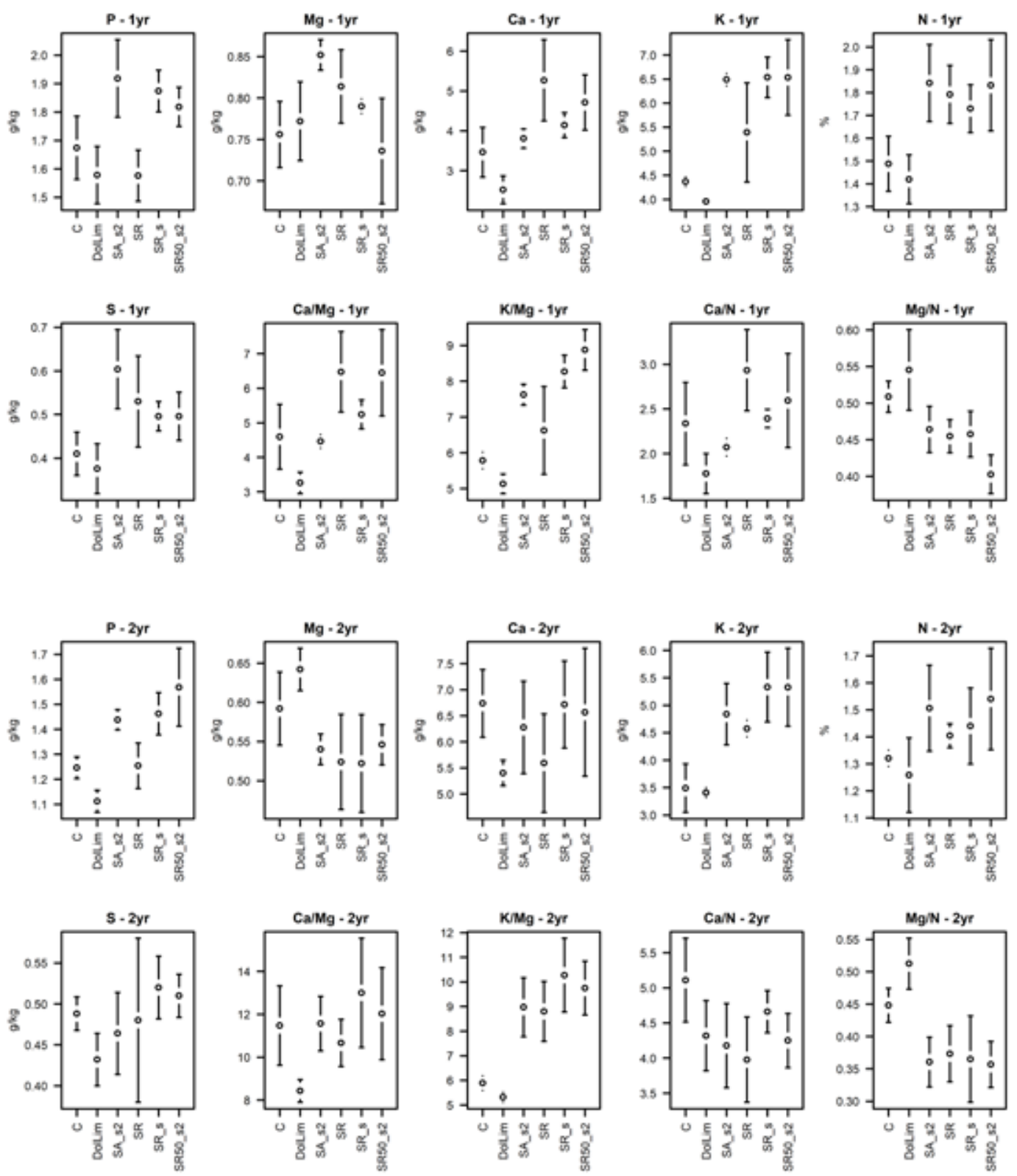

Fig. 3. Content of the nutrients in one-year-old needles (a) and two-year-old needles (b) in the individual treatments, expressed as the post-hoc multiple comparisons with the mean values and $95 \%$ confidence intervals. (for the abbreviations, explanations see Materials and Methods Section and Table 1).

lent ammonium ion $\left(\mathrm{NH}_{4}^{+}\right)$with comparable lyotropic properties.

The $\mathrm{Ca} / \mathrm{Al}$ and $\mathrm{Bc} / \mathrm{Al}$ ratios contribute to the optimum level of soil chemistry in addition to absolute concentrations. These ones are at very low levels (far below 1 , even below 0.2 ) in most cases, which has already been considered a significant environmental risk (Cronan \& Grigal 1995; Vanguelova et al. 2007).

Nevertheless, the growth and nutritional responses of the stand are differentiated, although this ratio had not been significantly differentiated by any measure. On the contrary, the biomass production and the health status are the most favourable at treatments with combined fertilizers supplemented with the growth regulators. However, it should be noted that a considerable number of the literature (including that one listed here) operates with the $\mathrm{Ca} / \mathrm{Al}$ and $\mathrm{Bc} / \mathrm{Al}$ ratios in the soil solution, not the soil sorption complex. Nonetheless, according to the ratio law (Schofield 1947 in White 2006), it is also possible to take this ratio into account as a guideline for the assessment of soil chemistry.

The higher nitrogen content in values up to the supraoptimal concentration (Table 4) for DolLim can result in its accelerated mineralization and loss from the root zone not only of nitrogen, but also to equivalent loss of Mg, Ca and K (Huettl \& Zoettl 1993). In soil chemistry 
with the $\mathrm{C} / \mathrm{N}$ ratio lower than 30 and ammonia nitrogen form dominance, mineralization and nitrification lead to the increase in $\mathrm{H}^{+}$concentration and acidification of lower soil parts and heavy metals mobilization. Hence the amelioration on one side can be interlinked to the risk of nitrogen leaching (Huettl \& Zoettl 1993; Vesterdal \& Raulund-Rasmussen 2002), on the other side, it can precede nitrogen immobilization via biological fixation when the $\mathrm{C} / \mathrm{N}$ ratio higher than cca 30-35 (Kai et al. 1969; White 2006).

The growth responses were not significantly different in the annual growth (Table 5) but showed the lowest effect in the DolLim treatment, which corresponded with the lowest vitality. The lowest biomass production in oneyear-old needles was in DolLim treatment and the highest in SR_s treatment; in two-year-old needles the needles biomass production was not under the direct influence of the treatments as the needles developed before the experiment commencement.

The effect of treatments on the assimilation organ development was documented in the factorial plane (Fig. 4); in one-year-old needles, the vector of the HundNeedl categorical variable evinced a slight negative relation in DolLim, while in two-year-old needles, the same vector manifested no relation with the treatment.

The element content in biomass and nutritional balance were highlighted in Table 6 and Fig. 3, with a detailed representation of the graphical display of the PCA (Fig. 4). The cumulative proportion of explained variability with the first two principal components was $53.02 \%$ and $53.76 \%$ for dataset with one-year-old and two-year-old needles, respectively. In one-year-old assimilation organs (Fig. 4a), the Mg nutrient concentration was relatively unresponsive to $\mathrm{Ca}$, and its intake was bound to the Silvamix compound fertilizers. In the $\mathrm{C}$

a)

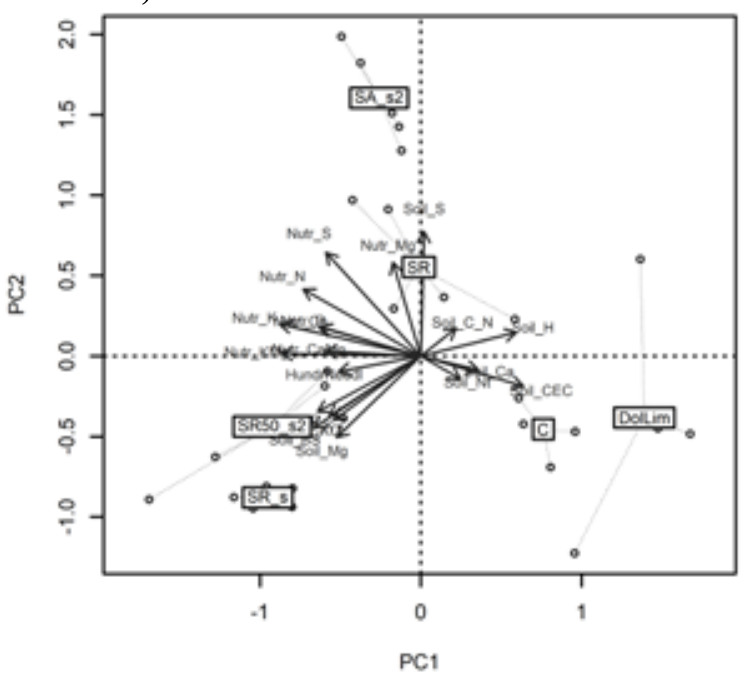

and DolLim treatments, potassium was at the lower optimum limit, especially in the two-year-old needles. In the two-year-old needles (Fig. 4b), the K/Mg nutrient ratio was completely antagonistic; $\mathrm{Mg}$ was forwarded at the expense of $\mathrm{K}$, and $\mathrm{Mg}$ was distributed to a younger needle year-class (da Silva et al. 2011) while presenting a deficiency due to a suboptimal intake during the dry period throughout the vegetation. In connection with the initial natural (soil) conditions, the question is the legitimacy of forest ecosystem subsidy with magnesium, which was in the optimum values in the soil within the particular area and yet did not enter into nutrition due to the limited income in relation to its hydration requirements (Gransee \& Führs 2013) that manifest during the short-term drought in the growing season. Thus, Mg is still within the optimum range in one-year needles while it is below the limit of deficiency in two-year needles. Furthermore, when using combined fertilizers, the $\mathrm{K} / \mathrm{Mg}$ ratio was more optimized than $\mathrm{C}$ and DolLim.

Based on herein results and other works, fertilization and amelioration of forest ecosystems still seem to be questionable measures and many research studies provide contradictory interpretations, depending on forest management, as well (Podrázský 1994; Nilsson et al. 2001; Sjöberg et al. 2004; Remeš et al. 2005; Vacek et al. 2006; Vavříček et al. 2010; Šrámek et al. 2012). Compared to agrosystems, where liming is an essential part of the soil environment care (Goulding 2016), the overhead humus forms that are typical of forest soils (Klinka et al. 1990) represent a significant buffering factor (James \& Riha 1986), as well as an important nutrient reservoir. From this perspective, it seems to be auspicious to repeat the investigation in the longer time horizon.

Soil buffering is a significant factor affecting the liming efficiency, especially treatments targeting elevated

b)

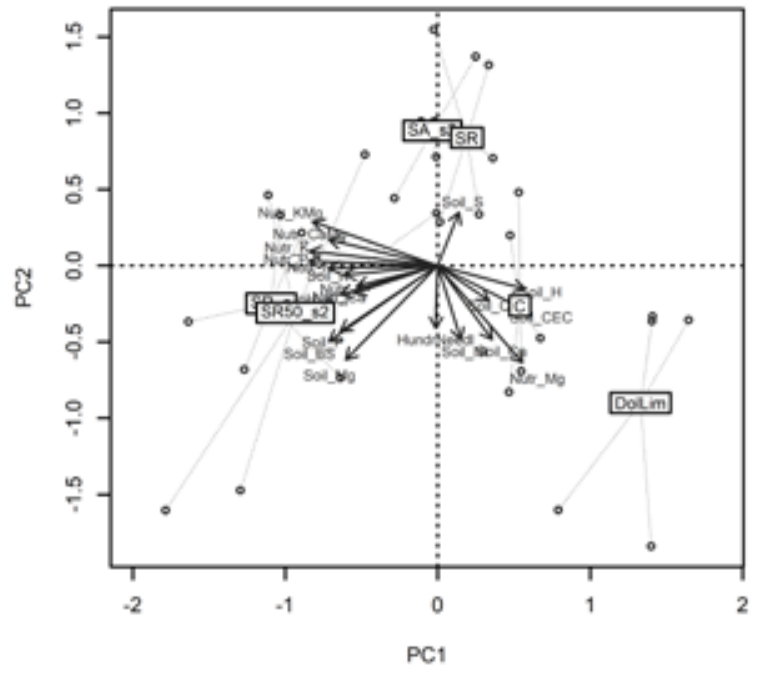

Fig. 4. PCA ordination graph illustrating the relation between categorical variables and the individual treatments (a): concerning the nutritional status of one-year-old needles; (b) concerning the nutritional status of two-year-old needles (for the abbreviations, explanations see Materials and Methods Section and Table 1). 
mountainous locations with a naturally acidic soil reaction $(\mathrm{pH} / \mathrm{KCl}$ even $<3.0)$ in the podzol soil zone. In organo-mineral and mineral horizons, the buffering capacity extends to the exchange zone and even down to the aluminium zone (Matzner 1992). Liming of these habitats results in conflicts related to the paradoxical application of the carbonate buffering zone in the naturally occurring buffer zone of iron and aluminium. Based on the frequently contradictory standpoints, the positive effect of liming (especially the air largescale) is not unquestionable. Hence, beside the routine soil parameters $(\mathrm{pH}$, exchangeable nutrient content, base saturation), the nutritional status of the stand, the forest floor vegetation and site conditions should be individually examined.

\section{Conclusion}

The combined fertilizers use in the forest ecosystems was more effective for soil chemistry, the plant growth, as well as the nutrition status compared to the dolomitic limestone. Liming negatively affected the nutrient status of the soil and plants in comparison with the effects of compound fertilizers and caused disproportionate nutrient levels on soil colloids and nutritional imbalances.

Liming can significantly impact ion exchange processes in the soil sorption complex, the soil chemical status and, consequently, biological activities, mineralization processes, humus conditions, the plant nutrition and health statuses.

Soil chemistry, nutrition status and biometrical parameters of the Norway spruce individuals were positively affected using combined fertilizers. In addition to liming, there are alternative amelioration methods, e.g. the application of compound fertilizers containing a wide range of macrobioelements using nanotechnologies, such as growth regulators, for improving tree vitality, metabolism, nutrient uptake and root system development.

Individual application of ameliorative materials is optimal method for stands with juvenile development stage.

\section{Acknowledgement}

The study was funded by the project QJ1320040 (Ministry of Agriculture, Czech Republic). It was also supported by the projects QK1920328 (Ministry of Agriculture, Czech Republic) andIGA_PSV_2017008 (MendelUniversity in Brno, Faculty of Forestry and Wood Technology).

\section{References}

Adams, F., Evans, C. E., 1990: A rapid method for measuring lime requirement of yellow podzolic soils. Soil Science Society of America Journal, 26:355-357.

Augusto, L., Ranger, J., Binkley, D., Rothe, A., 2002: Impact of several common tree species of European temperate forests on soil fertility. Annals of Forest Science, 59:233-253.

Bäck, J., Huttunen, S., Turunen, M., Lamppu, J., 1995: Effects of acid rain on growth and nutrient concentrations in Scots pine and Norway spruce seedlings grown in a nutrient-rich soil. Environmental Pollution, 89:177-87.

Baláš, M., Kuneš, I., Zahradník, D., 2010: Reaction of Carpathian birch on liming and nitrogen fertilization. Zprávy lesnického výzkumu, 55:106-115.

Cronan, C. S., Grigal, D. F., 1995: Use of calcium/aluminum ratios as indicators of stress in forest ecosystems. Journal of Environmental Quality, 24:209-226.

da Silva, E. C., Nogueira, R. J. M. C., da Silva, M. A., de Albuquerque, M. B., 2011: Drought stress and plant nutrition. Plant Stress 5 (Special Issue 1):32-41.

Formánek, P., Vránová, V., 2003: A contribution to the effect of liming on forest soils: review of literature. Journal of Forest Science, 492:182-190.

Goulding, K. W. T., 2016: Soil acidification and the importance of liming agricultural soils with particular reference to the United Kingdom. Soil Use and Management, 32:390-399.

GranseeA., Führs, H., 2013: Magnesium mobility in soils as a challenge for soil and plant analysis, magnesium fertilization and root uptake under adverse growth conditions. Plant Soil, 368:5-21.

Hruška, J., Ciencala, E. (eds.), 2005: Dlouhodobá acidifikace a nutriční degradace půd - limitující faktor současného lesnictví (in Czech). Praha, Česká geologická služba, $153 \mathrm{p}$.

Huang, J., Jiangming, M., Zhang, W., Xiankai, L., 2014: Research on acidification in forest soil driven by atmospheric nitrogen deposition. Acta Ecologica Sinica, 34:302-310.

Huettl, R. F., Zoettl, H. W., 1993: Liming As a Mitigation Tool in Germany Declining Forests - Reviewing Results From Former and Recent Trials. Forest Ecology and Management, 61:325-338.

Ingerslev, M., 1999: Above ground biomass and nutrient distribution in a limed and fertilized Norway spruce (Picea abies) plantation. Part I. Nutrient concentrations. Forest Ecology and Management, 119:13-20.

Ingerslev, M., Hallbäcken, L., 1999: Above ground biomass and nutrient distribution in a limed and fertilized Norway spruce (Picea abies) plantation. Part II. Accumulation of biomass and nutrients. Forest Ecology and Management, 119:21-38.

James, B. R., Riha, S. J., 1986: pH Buffering in Forest Soil Organic Horizons: Relevance to Acid Precipitation. Journal of Environmental Quality, 15:229-234. 
Kai, H., Ahmad, Z., Harada, T., 1969: Factors affecting immobilization and release of nitrogen in soil and chemical characteristics of the nitrogen newly immobilized: I. Effect of Temperature on Immobilization and Release of Nitrogen in Soil. Soil Science and Plant Nutrition, 15:207-213.

Kirk, P. L., 1950: Kjeldahl Method for Total Nitrogen. Analytical Chemistry, 22:354-358.

Klimo, E., Vavříček, D., 1991: Acidifikace a vápnění lesních půd v Beskydech. Lesnictví - Forestry, 37: 61-72.

Klinka, K., Wang, Q., Carter, R. E., 1990: Relationships Among Humus Forms, Forest Floor Nutrient Properties, and Understory Vegetation. Forest Science, 36:564-581.

Kreutzer, K., 1995: Effects of forest soil liming on soil processes. Plant and Soil, 168:447-470

Kulhavý, J., Marková, I., Drápelová, I., Truparová, S., 2009: The effect of liming on the mineral nutrition of the mountain Norway spruce (Picea abies L.) forest. Journal of Forest Science, 55:1-8.

Kuneš, I., 2003: Prosperity of spruce plantation after application of dolomitic limestone powder. Journal of Forest Science, 49:220-228.

Kuneš, I., Baláš, M., Balcar, V. et al., 2013: Effects of fertilisation on growth and nutrition of Norway spruce on a harsh mountain site. Journal of Forest Science, 59:306-318.

Lomský, B., Šrámek, V., Maxa, M., 2006: Fertilizing measures to decrease Norway spruce yellowing. Journal of Forest Science, 52:65-72.

Matzner, E., 1992: Acidification of forests and forest soils: Current status. Studies in Environmental Science, 50:77-86.

Mehlich, A., 1978: New extractant for soil test evaluation of phosphorus, potassium, magnesium, calcium, sodium, manganese and zinc 1 . Communication in Soil Science and Plant Analysis, 9:477-492.

Merry, R. H., 2009: Acidity and alkalinity of soils. In: Sabljic, A. (ed): Environmental and Ecological Chemistry. Eolss Publishers Co. Ltd. Oxford, UK, p. 115-131.

Nilsson, I. S., Andersson, S., Valeur, I. et al., 2001: Influence of dolomite lime on leaching and storage of $C$, $\mathrm{N}$ and $\mathrm{S}$ in a spodosol under Norway spruce (Picea abies [L.] Karst.). Forest Ecology and Management, 146:55-73.

Novotný, R., Lachmanová, Z., Šrámek, V., Vortelová, L., 2008: Air pollution load and stand nutrition in the Forest District Jablunkov, part Nýdek. Journal of Forest Science, 54:49-54.

Pecháček, J., Vavříček, D., Kučera, A., Dundek, P., 2017: The effect of slow-release fertilizers on the soil environment of spread windrows in the Krušné Hory Mts. Journal of Forest Science, 63:331-338.
Podrázský, V., 1994: Provozní vápnění v Krkonoších. Opera Corcon, 31:59-70.

Remeš, J., Podrázský, V., Ulbrichová, I., Meduna, V. 2005: Fertilization of Norway spruce plantations on the bulldozer-spread windrows in the Ore Mts . Journal of Forest Science, 51:49-53.

Sardans, J., Peñuelas, J., 2015: Potassium: A neglected nutrient in global change. Global Ecology and Biogeography, 24:261-275.

Seaby, D. A., Selby, C., 1990: Enhanced Seedling Root Development in 8 Conifer Species Induced By Naphthalene Acetic-Acid. Forestry, 63:197-207.

Simpson, D. A., 1986: Auxin stimulates lateral root formation in container grown interior Douglas-fir seedlings. Canadian Journal of Forest Research, 16:1135-1139.

Singh, A., Agrawal, M., 2008: Acid rain and its ecological consequences. Journal of Environmental Biology, 29:15-24.

Sjöberg, G., Knicker, H., Nilsson, S. I., Berggren, D., 2004: Impact of long-term N fertilization on the structural composition of spruce litter and mor humus. Soil Biology and Biochemistry, 36:609-618.

Sokolov, A. V., 1939: Determination of exchangeable Al in soil. Chemizacija socialističeskogo zemledelija, $7: 30-35$.

Šrámek, V., Fadrhonsová, V., Vortelová, L., Lomský, B. 2012: Development of chemical soil properties in the western Ore Mts. (Czech Republic) 10 years after liming. Journal of Forest Science, 58:57-66.

Strížová, I., 2014: Jednotné pracovní postupy, Analýza rostlinného materiálu. ÚKZÚZ (Central Institute for Supervising and Testing in Agriculture), Brno.

Vacek, S., Podrázský, V., Hejcman, M., Remeš, J., 2006: Effect of $\mathrm{Mg}$ fertilization on yellowing disease of Norway spruce at higher elevations of the Šumava Mts., Czech Republic. Journal of Forest Science, 52:474-481.

Vanguelova, E.I., Hirano, Y., Eldhuset, T.D., et al. 2007: Tree fine root $\mathrm{Ca} / \mathrm{Al}$ molar ratio - Indicator of $\mathrm{Al}$ and acidity stress. Plant Biosyst 141:460-480.

Vavříček, D., Pecháček, J., Jonák, P., Samec, P. 2010: The effect of point application of fertilizers on the soil environment of spread line windrows in the Krušné hory Mts. Journal of Forest Science, 56:195-208.

Vavř́ček, D., Samec, P., Šimková, P., 2005: Soil properties as a component of predisposition factors of Norway spruce forest decline in the Hanušovická highland mountain zone. Journal of Forest Science, 51:527-538.

Vavříček, D., Kučera, A., 2017: Základy lesnického půdoznalstvía výživy lesních dřevin. Lesnická práce, Kostelec nad Černými lesy, 364 p.

Vesterdal, L., Raulund-Rasmussen, K., 2002: Availability of nitrogen and phosphorus in Norway spruce forest floors fertilized with nitrogen and other essential nutrients. Soil Biolchemistry, 34:1243-1251. 
White, R. E., 2006: Principles and Practice of Soil Science: the Soil as a Natural Resource, fourth. Blackwell, Oxford.
Regulation (EC) 2003/2003 (2003) Regulation (EC) No 2003/2003 of the European Parliament and of the Council of 13 October 2003 relating to fertilisers.

Other sources:

IUSS Working Group WRB, 2014: World Reference Base for Soil Resources 2014, update 2015 International soil classification system for naming soils and creating legends for soil maps. World Soil Resources Reports No. 106. FAO, Rome.

\section{List of Abbreviations}

\begin{tabular}{|c|c|}
\hline aov & -ANOVA \\
\hline $\mathrm{Bc}$ & - base cations \\
\hline $\mathrm{C}$ & - control \\
\hline CEC & - cation exchange capacity \\
\hline DolLim & - dolomitic limestone \\
\hline GrowAnn & - annual height increment \\
\hline Health & - health status \\
\hline HundrNeedl & - weight of 100 needles \\
\hline $\mathrm{K}-\mathrm{W}$ & -Kruskal-Wallis test \\
\hline Nutr_P, Mg, Ca, K, N, S, CaMg, KMg & - nutrient content in needles and the nutrient ratio \\
\hline SA_s 2 & -AGLUFORM ${ }^{\circledR 9} 90+\mathrm{s} 2$ \\
\hline Soil_BS & - base saturation \\
\hline Soil_C_N & $-\mathrm{C} / \mathrm{N}$ ratio \\
\hline Soil_Ca, Mg, K, P, S, Nt, H & - element content in soil \\
\hline Soil_CEC & - cation exchange capacity \\
\hline Soil_pH_H $\mathrm{H}_{2} \mathrm{O}$ and Soil_pH_KCl & - active and exchangeable soil reaction, respectively \\
\hline SR & - Silvamix ${ }^{\circledR} R 30$ \\
\hline SR_S & - Silvamix ${ }^{\circledR} \mathrm{R} 30+\mathrm{s}$ \\
\hline SR50_s2 & - Silvamix ${ }^{\circledR} \mathrm{R} 50+\mathrm{s} 2$ \\
\hline
\end{tabular}

